\title{
IMPLEMENTATION OF THE EUROPEAN UNION REQUIREMENT TO COORDINATE ACTIVITIES OF PUBLIC ADMINISTRATION AUTHORITIES IN THE PROCESS OF THE AUTHORISATION, CERTIFICATION, AND LICENSING OF RENEWABLE ENERGY SOURCES INVESTMENTS
}

\author{
Kamila Sobieraj*
}

\begin{abstract}
The aim of this article is analysis of one of the barriers to the functioning of procedures for authorization, certification, and licensing of renewable energy sources (RES) investments - lack of coordination in actions of the public administration authorities while conducting those procedures, both in the context of EU law, as much national laws of selected Member States. Why this barrier is still dominant? The article is devoted to the analysis of possible and applied models for such coordination in the area of RES investments. Attention has also been drawn to restrictions that should be taken under consideration by the Member States while the regulations regarding procedures coordination implementing. Constructing and applying of coordination of public administration authorities activities in such a way as it might contribute to streamlining and accelerating administrative procedures in the area of RES investments and consequently achieve a designated RES energy share in the final gross energy consumption, is not an easy task. Inappropriately constructed and applied mechanisms may lead to an exactly opposite effect.
\end{abstract}

Key words: effectiveness of public administration, EU implementation, renewable energy sources

Kamila Sobieraj, PhD in Law, Associate Professor at the Public Economic Law Department, the Faculty of Law, Canon Law and Administration, The John Paul II Catholic University of Lublin, e-mail: sobieraj@kul.pl, ORCID 0000-0001-6432-4977 


\section{INTRODUCTORY ISSUES}

Obtaining permissions or other approvals necessary for executing renewable energy sources (RES) investments requires carrying out of procedures, in particular regarding environmental protection law, spatial planning and management law, as well as construction law. Following the analysis of the Member States' reports regarding the functioning of the national procedures for the authorization, certification, and licensing of RES, in summative report 2005, the European Commission indicated three categories of barriers to be dealt with by investors operating in the EU Member States ${ }^{1}$. These barriers resulted in delays throughout the investment process, which in turn led to a slowdown in achieving a particular contribution of renewable energy sources to gross final energy consumption particular share. Firstly, there was the effect of not taking RES sufficiently into account in spatial planning. In many countries and regions, the future development of RES projects has not been included in land development plans, in particular by not designating proper areas for wind energy projects and biomass energy projects. Secondly, in their summative report, the European Commission pointed out the complexity and vagueness of the procedures, and thirdly, the large number of authorities involved and the lack of coordination between them ${ }^{2}$. Although Member States have made some progress on reducing administrative burdens regarding executing RES investments during recent years, in their report 2017 the European Commission indicated that administrative barriers have still remained within that investment process (Commission emphasized mainly that one-stop shops have not been implemented and automatic permissions have not been granting after the deadlines) ${ }^{3}$.

The reference book, however, emphasize the point that investors implementing other types of infrastructural projects struggle with the same

1 Commission of the European Communities, Communication from the Commission. The support of electricity from renewable energy sources, Brussels, 7.12.2005. $\operatorname{COM}(2005) 627$ final, 15.

2 Ibidem, p. 14.

3 European Commission, Report from Commission to the European Parliament, the Council, the European Economic and Social Committee and the Committee of the Regions, Renewable Energy Progress Report, Brussels, 1.2.2017 COM(2017) 57 final. 
problems $s^{4}$. It must be added, however, that in case of the investment process regarding RES, the aforementioned barriers, and in particular the high number of public administration authorities involved and the lack of coordination between their activities, are becoming especially widespread ${ }^{5}$. The reason for a much higher scale (intensity) of the aforesaid barriers in the investment process regarding RES is the multitude of acts in different branches of law and, consequently, the obligations for investors arising from them with regard to obtaining permissions or other approvals necessary for the implementation of the RES investment process. According to Marjan Peeters and Thomas Schomerus "the whole legal package applicable to renewable energy activities could be described as a "maze": understanding the whole framework of laws applicable to a specific activity is a complicated task"'. The authors point out such areas of legal regulations as the environmental impact assessment law, spatial planning and construction law, nature conservation law, the industrial emissions law, and energy efficiency law7. Furthermore, they emphasize that "apart from the above list of applicable laws, specific EU and national legal standards may be relevant depending on the nature of the renewable energy project" (biomass installation, water energy installation, a wind farm).

There are definitely more far-reaching consequences for RES investments following the existence of the aforementioned barriers, influencing the length of the entire investment process compared to other infrastructural projects. EU law (currently still Directive 2009/28/EC of the European Parliament and of the Council dated 23 April 2009 on the promotion of

4 Kars de Graaf, Albert Marseille, "Towards efficient administrative procedures for renewable energy projects? The Dutch experience with the Crisis and Recovery Act", In: Renewable Energy Law in the EU: Legal Perspectives on Bottom up-approaches, ed. Marjan Peeters, Thomas Schomerus, Cheltenham-Northampton: Edward Elgar Publishing, 2014, 123.

Ibidem.

6 Marjan Peeters, Thomas Schomerus, "An EU law perspective on the role of regional authorities in the field of renewable energy", In: Renewable Energy Law in the EU: Legal Perspectives on Bottom up-approaches, ed. Marjan Peeters, Thomas Schomerus, Cheltenham-Northampton: Edward Elgar Publishing, 2014, 23.

7 Ibidem, 21.

8 Ibidem, 22. 
the use of energy from renewable sources and amending and subsequently repealing Directives 2001/77/ and 2003/30/EC ${ }^{9}$ ) establishes binding national shares of energy from renewable sources in the overall community energy consumption for the Member States ${ }^{10}$. A delay in the RES investment process leads to a slowdown in meeting national targets. Failure to meet that targets may, consequently, be connected with a specific liability of a Member State (which is not the case with regard to other infrastructural projects). Furthermore, with reference to the new directive 2018/2001 of the European Parliament and of the Council dated 11 December 2018 on the promotion of the use of energy from renewable sources ${ }^{11}$, it must be taken into account that, in the future years, EU requirements regarding the necessary share in energy from renewable resources to be gained in the final energy consumption shall increase. In the context of increasing EU requirements with regard to RES, streamlining and expediting administrative procedures in the area of RES investment implementation is becoming more and more important. It also proves the importance of the topic discussed in that article.

The aim of this article is to provide an analysis of one of the above-mentioned barriers to the functioning of procedures for the authorization, certification and licensing of RES investments - the lack of coordination in the actions of public administration authorities in the process for obtaining permissions or other types of approvals necessary to implement RES investments, in the context of EU law as much as in the national laws of selected Member States. The thesis of the article is that the introduction of a specific model of coordination in the actions of public administration authorities requires a comprehensive consideration of many factors in the context of the particular Member State legal order. If not carefully considered, a given model of coordination in the actions of public administration authorities shall bring the opposite effect from the intended one (delay or even blocking the RES investment process).

9 OJ L 140/16, dated 05.06.2009, further referred to as “directive 2009/28/EC".

10 See also: Mariusz Szyrski, Rola samorządu terytorialnego w rozwoju odnawialnych źródeł energii (OZE). Analiza administracyjnoprawna, Warsaw: Wolters Kluwer, 2017, 57-58; Anna Bohdan, Monika Przybylska, Podstawy prawne odnawialnych źródeł energii i gospodarki odpadami w Polsce, Warsaw: C.H. Beck, 2015, 1-5.

11 OJ L 2018.328.82, dated 21.12.2018, further referred to as “directive 2018/2001". 
Firstly, this article is discussing the scope (including the evolution process) of EU requirements with regard to coordinating the activities of public administration authorities involved in the process of the authorization, certification and licensing of RES investments. The Directive 2009/28/ EC and Directive 2018/2001 provisions specifying requirements for coordination of the activities of public administration authorities have a wide scope of generality, discretion, and even vagueness. However, it shall be also proving (in the following part of the article) that the EU requirements for the coordination in the activities of public administration authorities within the RES investment process are not only those contained in Article 13 of Directive 2009/28/EC and Article 15 of Directive 2018/2001. Due to the fact that the provisions of EU law do not indicate a specific model of coordination that should be implemented by the Member States, the author tries to outline the possible models for such coordination in the area of RES investments. Attention has also been drawn to possible dilemmas the EU Member States may encounter introducing regulations for coordinating procedures (failure to consider them may result in that the given model for coordination may have the opposite effect than intended). Thirdly, this article is presenting a deficit of proper legal regulations with regard to the coordination of public administration activities, issuing permissions or other types of approvals necessary to carry out wind farm projects within the legal framework of Poland. The Polish institution of "cooperation" in proceedings regarding the assessment of wind farms' impact on the environment seems to be heading in the "opposite" direction ${ }^{12}$. These forms of coordination must be implemented in a well-thought and "individualized" way, not "automatic" taken over from the other Member States.

The basic research method used in the article is the dogmatic and legal method (analysis of legal acts, principles of law).

12 Filip Marek Elżanowski, Maciej Miłosz Sokołowski, "Proces inwestycyjny w kontekście pakiety klimatyczno- energetycznego Unii Europejskiej”, In:, Energetyka i ochrona środowiska w procesie inwestycyjnym, ed. Maksymilian Cherka, Filip Marek Elżanowski, Mariusz Swora, Krzysztof Andrzej Wąsowski, Warsaw: Wolters Kluwer, 2010, 133. 


\section{THE EU REGULATIONS WITH RESPECT TO COORDINATING NATIONAL PUBLIC ADMINISTRATION AUTHORITIES' ACTIONS WITH REGARD TO RES INVESTMENTS IMPLEMENTATION}

EU law does not primarily interfere within the sphere of the organization of the Member States' administrative systems, or in the way, administrative procedures are applied. According to the accepted rule of institutional and procedural autonomy, the responsibility of Member States includes deciding on the structure, competence, and mode of the national authorities' operations, including their appointment and liquidation ${ }^{13}$. Member States also maintain their organizational and procedural autonomy when this is connected with implementing EU law. Each Member State is, however, responsible for organizing their structures, and for the division of competence, as well as constructing and carrying out administrative procedures, so that particular tasks resulting from the EU law could be properly carried out (autonomy rule is limited by the rule of equivalence and effectiveness $\left.{ }^{14}\right)$.

For the EU legislator, the issue of increasing the effectiveness and pace of administrative procedures within RES investments to achieve a specific percentage of RES share in the final gross energy consumption may be confirmed by the fact the EU legislator has referred to the issue in the very first EU directive regarding RES, i.e. in Directive 2001/77/EC of the European Parliament and of the Council of September 2001 on the promo-

13 See also: Zbigniew Kmieciak, „Zasada autonomii proceduralnej państw członkowskich UE i jej konsekwencje dla procesu orzekania przez sądy administracyjne i organy administracji publicznej”, Zeszyty Naukowe Sądownictwa Administracyjnego 2(2009): 9-25; Andrzej Wróbel, „Autonomia proceduralna państw członkowskich. Zasada efektywności i zasada efektywnej ochrony sądowej w prawie Unii Europejskiej”, Ruch Prawniczy, Ekonomiczny i Socjologiczny 1(2005): 35-58; Maciej Taborowski, Konsekwencje naruszenia prawa Unii Europejskiej przez sądy krajowe, Warsaw: Wolters Kluwer, 2012, 48-50.

14 See also: Sebastian Gajewski, „Wzruszenie ostatecznej decyzji administracyjnej z powodu jej niezgodności z wykładnią prawa UE przyjętą w późniejszym orzeczeniu TSUE (w świetle k.p.a.)", In: Europeizacja prawa administracyjnego i administracji publicznej ed. Ewa Wójcicka, Bogusław Przywor, Częstochowa: Akademia Jana Długosza 2016, 166; Piotr Brzeziński, Unijny obowiązek odmowy zastosowania przez sąd krajowy ustawy niezgodnej z dyrektywą Unii Europejskiej, Warsaw: Wolters Kluwer, 2010, 50-93; Maciej Taborowski, supra note 13, 259. 
tion of electricity produced from renewable energy sources in the internal electricity market ${ }^{15}$. Bearing in mind the principle of institutional and procedural autonomy, Directive 2001/77/EC did not impose upon the Member States any obligation to introduce a particular way of coordinating the actions of public administration authorities while conducting procedures regarding RES investments ${ }^{16}$. The resolutions of art. 6 of Directive 2001/77/EC only required the Member States to evaluate their existing administrative procedures, establishing that they do not pose a barrier or hamper the Directive's indicative goals. In the reports of the Member States regarding the evaluation though, there ought to have been a degree of advancement concerning actions, among others, to coordinate the work of different administrative authorities with respect to the terms, accepting and processing applications to grant permissions.

The issue of assuring coordination between administration authorities concerning carrying out procedures of RES investments for authorization, certification and licensing became important during works at the next directive. In point 24 of the introduction to the proposal presented by the European Commission on 23 January 2008 of the new RES Directive, it was indicated that "the lack of transparent rules and coordination between the different authorization bodies has been shown to hinder the deployment of energy from renewable sources" ${ }^{17}$. In the reference sources ${ }^{18}$ we are reminded that the European Parliament's amendment to the above-quoted point 24 was worded as follows "A single administrative body responsible for all necessary authorizations should be established. That body should operate at the level closest to the projects, preferably at

15 OJ L 283/33, dated 27.10.2001, further referred to as „directive 2001/77/EC”. See also about this directive: Marcin Nowacki, Prawne aspekty bezpieczeństwa energetycznego Unii Europejskiej, Warsaw: Wolters Kluwer, 2010, 165-167; Mariusz Szyrski, supra note $10,49-50$.

16 Kars de Graaf, Albert Marseille, supra note 4, 124.

17 Commission of the European Community, Proposal for Directive of European Parliament and the Council on the promotion of the use of energy from the renewable sources, Brussels, 23.01.2008, (COM(2008) 30 final.

18 Kars de Graaf, Albert Marseille, supra note 4, 126. 
the municipal or regional level"19. This amendment was supported/justified by the fact that "The rapid deployment of renewable energies is often hindered by complicated procedures, too many layers of decision power and a lack of concentration. A one-stop shopping approach is desirable. But this should not mean that it is necessary that the permission authority would only lie at the national level" 20 . Although the amendment was not approved, in the reference sources it is stated it proves the significance, according to the EU institutions, of taking actions aimed at streamlining and accelerating RES administrative procedures ${ }^{21}$. The amendment expressed the idea of coordinating administrative procedures and introducing one administrative authority responsible for RES investments' authorization, certification and licensing in the Member States ${ }^{22}$.

Directive 2009/28/EC establishes more detailed (compared to Directive 2001/77/EC) requirements regarding procedures for the authorization, certification and licensing of RES investments, and also concerning coordinated administrative procedures. Provisions of art. 13 item 1 sentence 2 pt (a) of Directive 2009/28/EC the obligate Member States to take appropriate steps needed for a clear definition and coordination of administrative obligations concerning the national, regional and local administrative bodies responsible for authorization, certification and licensing procedures, including spatial planning. In the reference books, it is emphasized, however, that this criterion (plus other ones included in art. 13 item 1 sentence 2 of Directive 2009/28/EC) leaves a wide scope of generality, vagueness and thereby discretion to the Member States ${ }^{23}$. There are doubts about the scope of the obligation, i.e. to what extent the procedures must be coordinated ${ }^{24}$ (if a one-stop-shop administrative authority responsible for authorization, certification and licensing of RES investments is required).

19 Report of 26 September 2008 on the proposal for a directive of the European Parliament and of the Council on the promotion of the use of energy from the renewable sources (COM(2008)0019 - C6-0046/2008 - 2008/0016(COD)).

20 Ibidem.

21 Kars de Graaf, Albert Marseille, supra note 4, 126.

22 Ibidem.

23 Ibidem, 127.

24 Marjan Peeters, Thomas Schomerus, supra note 6, 22. 
The aim of new Directive 2018/2001 is, among others, to streamline and accelerate administrative procedures in the area of RES investments, including dealing with the lack of coordination between the different authorities issuing permits. According to the provisions of point 50 of the introduction to the directive 2018/2001, the lack of transparent rules and coordination between the different authorization bodies has been shown to hinder the deployment of energy from renewable sources. Providing guidance to applicants throughout their administrative permit application and granting processes by means of an administrative contact point is intended to reduce complexity for project developers and increase efficiency and transparency, including for renewables self-consumers and renewable energy communities". The Directive 2018/2001 provides for a modification of art. 13 item 1 of Directive 2009/28/EC (new art. 15 item 1) and introduces, among others, an additional art. 16. Article 15 item 1 of Directive 2018/2001 includes general guidelines according to which national rules concerning the authorization, certification and licensing procedures of the defined RES investments shall be proportionate and necessary and contribute to the implementation of the energy efficiency first principle. Article 16 item 1 of the Directive 2018/2001 introduces an obligation to set up an administrative contact point which shall coordinate the entire permit-granting process for applicants with respect to permits to build and operate plants and associated transmission and distribution network infrastructures for the production of energy from renewable energy sources. The aforesaid one-stop-shop shall guide the applicant through the application process in a transparent manner, provide the applicant with all necessary information, coordinate and involve, where appropriate, other authorities, and deliver a legally binding decision at the end of the process. The one-stop-shop shall coordinate conducting, or be responsible for conducting, all the necessary procedures. Following the rule of institutional and procedural autonomy, the Directive 2018/2001 shall leave the Member States with a choice for the organization and scope of the contact point tasks. 


\section{AN OUTLINE OF POSSIBLE FORMS OF COORDINATING THE ACTIVITIES OF NATIONAL ADMINISTRATION AUTHORITIES}

In view of a general nature of Member States' duties, allowing a wide scope of discretion, included in art. 13 item 1 sentence 2 point (a) of Directive 2009/28/EC and in art. 15 item 1 of Directive 2018/2001, with regard to assuring coordination of administration authorities activities in the scope of RES investments, it might be assumed coordination may have different forms. Making an attempt to be precise about the necessary scope of coordinating administration authorities' actions in the area of RES investments administrative procedures, above all the aim, which the introduced forms of coordination must carry out, needs to be taken into account, i.e. streamlining and accelerating the investment process, and consequently achieving a particular share of the RES application. Certainly, we shall not achieve this at "the expense" of rights and freedoms, limiting rights connected with the institution of public participation or the right to file the measures of appeal (e.g. by excessive reduction of terms to apply those rights, limiting the grounds for filing such measures or narrowing the range of entities entitled to appeal). Certainly, we will not achieve this either at the "expense" of the values and objectives for accomplishing of which the administrative procedures subject to coordination have been established (i.e. environmental protection ${ }^{25}$, spatial $\operatorname{order}^{26}$, public security ${ }^{27}$ ) or the constitutional principles for shaping the structure

25 Regarding the values and objectives implemented by environmental law: Zbigniew Bukowski, "Aksjologiczne podstawy stanowienia prawa ochrony środowiska", In: Aksjologia prawa administracyjnego.Volume II, ed. Jan Zimmermann, Warsaw: Wolters Kluwer, 2017, 233-242.

26 Regarding the values and objectives implemented by spatial development law: Marek Szewczyk, "Aksjologia prawa zagospodarowania przestrzeni", In: Aksjologia prawa administracyjnego. Volume II, ed. Jan Zimmermann, Warsaw: Wolters Kluwer, 2017, $523-538$.

27 Regarding the values and objectives implemented by construction law: Dominik Sypniewski, "Bezpieczeństwo jako wartość podlegająca ochronie w procesie budowlanym”, In: Aksjologia prawa administracyjnego. Volume II, ed. Jan Zimmermann, Warsaw: Wolters Kluwer, 2017, 595-604. 
and competence of administrative authorities established in a given Member State.

Decisions issued in such proceedings shall raise public objections, doubts as to their material and procedural accuracy and they will be "opposed" or challenged by means of appeal, which shall lengthen the whole investment process. Legally defective permissions, or another type of approval, shall be a risk to the investor as, despite it being legally binding, it may still be revoked, which shall block the initiated investment process (the proceedings shall need to recommence). The investor needs streamlined and fast administrative procedures, but also certainty about the substantial and procedural accuracy of the permissions or approvals obtained. Constructing and applying administrative procedures within RES investments, including attempts to coordinate them, therefore requires careful consideration of different values and interests ${ }^{28}$.

The forms of coordinating the national administration authorities' actions for the procedures of authorization, certification and licensing of RES investments may be in either one of two categories: a) coordinating the work of two or more authorities (proceedings conducted by them) aimed at issuing all types of permissions or other approvals necessary to carry out RES investments ("external" coordination concerning some separate proceedings); b) coordinating the activities of an authority taking the decision in a case and authority or authorities giving opinions or affirmation within that case ("internal" coordination). So-called "external" coordination may also take different forms: a) one administration authority takes over the competence of several other authorities competent to carry out all the required procedures and issues one decision (a single joint proceeding and one decision); b) several administration authorities jointly examine all the cases and issue one decision; c) several administration authorities simultaneously examine all the cases and issue a few separate decisions (which may be separately appealed against).

The concept of one administrative authority, which takes over the competence of several authorities competent to consider all necessary cases within a single investment process and issues one decision, seems to be difficult to implement. At this point, it must be reminded that according

28 Marjan Peeters, Thomas Schomerus, supra note 6, 28 and 31. 
to the rule, the investment process regarding RES is regulated by many (a "maze") of acts in different areas of law, often requiring know-how in different fields). These acts of law are followed by numerous obligations related to various procedures necessary to obtain permissions or other types of approvals. It seems, therefore, that the concept of "one authority" may be considered only in case of very simple RES investment processes requiring few decisions and, additionally, in which specialist knowledge is not required. It must also be noted that one of the rules followed by the states while creating the national structure of administrative authorities is the rule of economic effectiveness (authority cost-effectiveness). For that reason, it is doubtful that the idea of setting up a specialist authority exclusively for carrying out the procedures regarding the investment process for particular types of RES investments may be implemented.

Another form of so-called "external" coordination of administration authorities' activities with respect to procedures of RES investments authorization, certification and licensing is the appointment of one complex administrative service contact point (a one-stop-shop). Its task is exclusively the coordination of currying out procedures, but not conducting of all procedures aimed at issuing permissions or other types of approvals (the investor contacts one authority). We may deal, in this case, with either a coordinated single decision-making process or coordinated processes of decision-taking (a few decisions). In both situations, several authorities participate, whereby in the first case one (joint) decision is issued, and in the latter case several (separate) decisions are issued.

It seems that also this form of coordinating the work of administrative authorities shall not be appropriate for all RES undertakings. Above all, in this situation, all highly complex undertakings must be excluded, where at the initial stage of the investment process the final decisions have not yet been taken, in particular with respect to technical or technological conditions of the investment implementation. It is highly likely that at a later stage, depending on the way "the situation develops", permission or another type of approval issued within such a coordinated procedure, shall have to be modified, and thus new proceedings shall have to be carried out.

In case of coordination in the form of appointing a one-stop-shop, it must be considered which authority may be entrusted with the function. Entrusting the central government authority with the function may be 
followed by an allegation of limiting the competence and the influence of local or regional authorities upon the decision-making process with regard to "their area"29. On the other hand, entrusting authority to the lowest level with the function may pose a risk with regard to their capacity to carry out the task properly. From the investor's point of view, it seems that the authority to which the investor applies for issuing the first decision within the investment process ought to be entrusted with such a function.

Some form of coordinating the work of administration authorities with regard to issuing permissions and other types of approvals for RES investments might also be the cooperation of the decision-taking authority and the authority or authorities responsible for expressing an opinion or approving within one administrative procedure. According to J. Zimmermann, "cooperation" is a notion defining a mutual way of administering subjects' interaction and it is a type of relation close to coordination that may only occur in a decentralized system ${ }^{30}$. The essence of "cooperation" means that the legislator entrusts one authority with the competence to take a substantial decision in the case, also encumbering the authority with the duty of obtaining an opinion of another authority in the course of the decision-taking process. The other authority is assigned the competence to take a stand or issue an opinion in the case decided by another authority. The institution of "cooperation" is used when the solving of a problem is beyond one authority's scope of activity (organization department), whereas it covers the scope of activity of two or more entities ${ }^{31}$. Owing to this institution, the legislator may limit the number of proceedings pending (decisions issued), within which it is necessary to consider a few issues that require knowledge in various fields, and thereby accelerate the whole investment process.

29 Kars de Graaf, Albert Marseille, supra note 4, 126.

30 Jan Zimmermann, Prawo administracyjne, Warsaw: Wolters Kluwer, 2012, $148-152$.

31 Stanisław Biernat, Działania wspólne w administracji państwowej, Wrocław: Ossolineum, 1979, 83-85. 


\section{EXAMPLES OF IMPLEMENTING THE COORDINATION OF ADMINISTRATIVE AUTHORITIES ACTIVITIES}

An example of Dutch law seems to confirm that the concept of "one authority" may be considered only in case of very simple RES investment processes. On 31 March 2010, the Crisis and Recovery Act (Crisis-en herstelwet) was included in the Dutch legal framework ${ }^{32}$. The law introduced special rules into the Dutch General Administrative Law Act (Algemene Wet Bestuursrecht) and into other laws. The law, having regard for mitigating the effects of economic crisis, established a few legal instruments aimed at streamlining and accelerating administrative procedures, including the idea of "one authority" 33 . The range of applying "one contact point" however, was very limited. The institution of "one authority", regulated in part II of the Crisis and Recovery Act, may be introduced exclusively for the purpose of "developing new housing districts formed of 12 up to 2,000 new houses" (mainly for the construction of houses and residential infrastructure $)^{34}$. The institution was based on integrating the process of decisions taken for the residential areas. The investor filed one application and one authority issued one integrated decision. If in a given case, regulations on public participation applied, the procedure was held once only ${ }^{35}$. The idea of "one authority" automatically "excluded" the competence of other authorities in relation to a particular project. The authority taking the decision in such an "integrated" case had to take into account all regulations referring to a given project (environmental law, spatial management law, regulations on water management and protection). The idea might not be used, however, in the situation wherein international or EU law-based regulations applied.

32 Kars Jan de Graaf, Hanna Dürtge Tolsma, "Country Report: The Netherlands. The Future Environment and Planning Act and the Impact of the Crisis and Recovery Act", IUCN Academy of Environmental Law e-Journal 6(2015): 293.

33 Katinka Jesse, "Country Report: The Netherlands. Big Changes in Environmental Planning Law On The Way”, IUCN Academy of Environmental Law e-Journal 4(2013): $178-179$.

34 Jonathan Verschuuren, 13 "The Dutch Crisis and Recovery Act: Economic Recovery and Legal Crisis?”, Potchefstroom Electronic Law Journal 5(2010): 9.

35 Ibidem, 198. 
The aforementioned Dutch Crisis and Recovery Law have also introduced the institution of a one-stop-shop for RES investments. The competence for drawing up and passing land use plans, which are binding for the process of RES investment location, has been divided among the local, provincial and national authorities in the Netherlands $s^{36}$. The Dutch Crisis and Recovery Law introduced into The Dutch Electricity Act (Electricitenitswet), regulations (art. 9e and $9 \mathrm{f}$ ) stating that a wind farm larger than $5 \mathrm{MW}$ and smaller than $100 \mathrm{MW}$ shall be considered as meeting the needs of a provincial spatial interest and the provincial public authority is also competent to adopt a land-use plan allowing for such wind farms $\mathrm{s}^{37}$. On the other hand, wind farms of over $100 \mathrm{MW}$ capacity are considered to meet the needs of national interest and national authorities have obtained proper competences. The national authorities, at the time they were adopting proper land use plans allowing the location of wind farms of over $100 \mathrm{MW}$ capacity, were also assigned competences regarding coordinating decision-taking with regard to permissions or other types of approvals needed to carry out the investments (art. 9b of The Electricity Act) ${ }^{38}$. Provincial authorities have been assigned not only competences to coordinate the decision-taking process, but they have also been assigned decision-taking competences with regard to other approvals regarding wind farms, which excluded, in that situation, competences of the local authorities ${ }^{39}$.

It seems that it would be difficult, however, to implement such construction in Poland. In the Polish law, issuing decisions with respect to spatial planning and management has been reserved for the local commune's authorities (the lowest level local government authorities). If in the light of the above, the function of the one-stop-shop is granted to the authority issuing the decision on investment location, doubts may occur if the Polish commune authority will be substantively able to guide the whole decision-making process in case of large land wind farms. At the same time, in Polish law the possibility of establishing a one-stop-shop to provide service for construction of offshore wind farms (following the pattern of Germany

\footnotetext{
36 Ibidem, 131.

37 Ibidem, 132.

38 Ibidem.

39 Ibidem.
} 
which has started such a (federal) institution with regard to offshore wind farms). Regulations of the Polish law on marine areas dated 21 March $1991^{40}$ provide for two location decisions: permission to erect and use artificial islands, constructions, and devices, as well as a decision establishing location and conditions of keeping cables or pipelines. Those decisions, as a rule, are issued (depending on the type of maritime area) by the minister appropriate for water economy or by the locally competent director of maritime office (art. 23 item 1 point 1 and 2).

In the process of implementing the one-stop-shop service, whose task is only to coordinate the conduct, and not to conduct all the required procedures, the most difficult issue seems to be the "selection" of the appropriate authority to which this role will be entrusted.

Inappropriate construction and application of a "cooperation" institution may, also, lead to exactly the opposite effect (even recommencement of the proceedings), which may be exemplified by the experiences of Poland in the use of the institution of "cooperation" at proceedings regarding the assessment of wind farms' impact upon the environment.

The investor willing to carry out a particular investment process (also within RES) in Poland is most often obligated to contact both the national and local government authorities, i.e. both general and special competence authorities. What is more, the structure of administrative authorities in Poland, including decision-making authorities (also within RES) has been shaped under the influence of decentralization rule included in the Constitution of the Republic of Poland dated 2 April $1997^{41}$, consisting above all in the process of regular extension of lower-level public authorities' competencies by entrusting them with tasks, competences and indispensable measures ${ }^{42}$ as well as the rule of subsidiarity. Unfortunately, in the Pol-

40 Dziennik Ustaw (English: Journal of Laws) of 2016, item 2145 as amended.

41 Dziennik Ustaw (English: Journal of Laws) of 1997 No. 78, item 483 as amended.

42 This principle is widely discussed in the literature of the subject, e.g. Ewa Jolanta Nowacka, Samorząd terytorialny jako forma decentralizacji administracji publicznej, Warsaw: Lexis Nexis, 2010, 15-31; Katarzyna Marszał, "Wpływ czynników zewnętrznych na samorząd terytorialny - analiza czynników ograniczających samodzielność jednostek samorządu terytorialnego", In: Samorząd terytorialny w Polsce a samorządowa kontrola administracji ed. Bogdan Dolnicki, Jan Paweł Tarno, Warsaw: Wolters Kluwer, 2012, 230-235; Dorota Dąbek, Jan Zimmermann, “Decentralizacja poprzez samorząd terytorial- 
ish law, the rule of decentralization and subsidiarity has been in many cases adopted "automatically" (that is without sufficient consideration of the possibility to perform the tasks efficiently, effectively and properly ${ }^{43}$ ) in issues that require highly specialist and diverse knowledge, which is not at disposal of the commune authorities in particular. To compensate for entrusting the resolving of cases, requiring know-how in the environmental protection field for their substantive correctness, general local government authorities without this kind of specialist knowledge seem to be served by an institution of "cooperation". However, inappropriately built and applied institution of "cooperation", in particular in the proceedings regarding the assessment of wind farms' impact upon the environment, led to a considerable lengthening of the investment process (in many cases the proceedings have been re-commenced) and even to block it.

Proceeding in case of assessment of the impact of wind farms upon the environment is in the Polish legal framework an example of the extensively developed model of cooperation, both in the subjective and objective scope $\mathrm{e}^{44}$. The proceedings are conducted at the stage of establishing conditions for an undertaking implementation, and in case of undertakings of potentially considerable impact upon the environment - also at the stage of establishing the obligation to carry out the assessment and establishing the range of the report. Carrying out such environmental impact assessment is obligatory in case of installations using wind energy to produce electricity of the total nominal power not lower than $100 \mathrm{MW}$ and located in marine areas ${ }^{45}$. In case of the other than the afore-men-

ny w ustawodawstwie i orzecznictwie pokonstytucyjnym”, In: Samorząd terytorialny. Zasady ustrojowe i praktyka, ed. Paweł Sarnecki, Warsaw: Wydawnictwo Sejmowe, 2005, 7-10.

43 Grzegorz Dobrowolski indicates that due consideration of these factors is a prerequisite for the correct application of the principle of decentralization and subsidiarity. Grzegorz Dobrowolski, "Authorities competent to issue a decision on the environmental conditions", In: Assessment of the legal model of environmental protection in Poland and Slovakia, ed. Elżbieta Ura, Jerzy Stelmasiak, Stanisław Pieprzny, Kosice: Equilibria, 2012, 259.

44 Małgorzata Szalewska, „Współdziałanie organów administracji publicznej w procedurze wydawania decyzji o środowiskowych uwarunkowaniach przedsięwzięcia”, In: Oceny oddziaływania na środowisko w praktyce, ed. Bartosz Rakoczy, Warsaw: Woltes Kluver, 2017,81 .

45 Rozporządzenie Rady Ministrów z dnia 9 listopada 2010 r. w sprawie przedsięwzięć mogących znacząco oddziaływać na środowisko (Regulation of the Council of Min- 
tioned installations located in areas covered by forms of nature protection (excluding installations intended exclusively for supplying road and railway signs, control or monitoring devices for road or rail traffic, navigation signs, lighting devices, and billboards), as well as of a total height not lower than $30 \mathrm{~m}$ - the obligation to carry out the assessment depends on the authority discretion. Until The Wind-farms Act took effect, the authority competent to issue a decision on the environmental conditions for a wind farm of the total installed generation capacity over $40 \mathrm{~kW}$ had been the commune's executive authority. Consequently, the cooperating (coordinating) authority with regard to the investment environmental constraints had been the Regional Director for Environmental Protection (RDEP), The State Sanitary Inspection, the Director of Maritime Office (in case of marine areas), as well as executive authorities of other communes, in case an undertaking extended beyond the area of one commune (currently this list has been extended) ${ }^{46}$.

In the legal framework in force until 16 July 2016 regarding wind farms of over $40 \mathrm{~kW}$ capacity, there were many doubts concerning the model of cooperation between the executive authority of a commune (as the authority examining the case) and the Regional Director for Environmental Protection (as the coordinating authority). Firstly, cooperation between the aforesaid authorities led to a diffusion of responsibility by way of defining the environmental conditions for the investment implementation. The decision-making authority ought to verify each time the stand of the cooperating authority, as it takes final responsibility for the result of proceedings. The ability to verify highly specialist findings and conclusions by an authority not being at disposal of such know-how, i.e. by the commune's executive authority, was highly doubtful, on the other hand.

Secondly, art. 77 item 7 of the law dated 3 October 2008 on access to information about the environment and its protection, on public participa-

isters of November 9, 2010 on projects that may significantly affect the environment), consolidated text Dziennik Ustaw (English: Journal of Laws) of 2016, item 71. See also: Dominik Jakub Kościuk, Artur Krzysztof Modrzejewski, „Farmy fotowoltaiczne i wiatrowe a ochrona środowiska w procesie inwestycyjnym - uwarunkowania prawne", In: Problemy pogranicza prawa administracyjnego i prawa ochrony środowiska, ed. Małgorzata Stahl, Piotr Korzeniowski, Aneta Kaźmierska-Patrzyczna, Warsaw: Wolters Kluwer, 2017, 287.

46. Małgorzata Szalewska, supra note 44, 88-89. 
tion in environmental protection, as well as on assessments of environmental impact ${ }^{47}$ excluded suability of the cooperation acts issued among others by the Regional Director for Environmental Protection (i.e. cooperation act issued by the RDEP in case of coordinating the conditions of an undertaking implementation). According to art. 142 of the administrative procedure code, a cooperation act that may not be complained against, may only be challenged by appealing against the final decision (decision on the environmental conditions). According to the Polish law, an appeal against matters connected with cooperation act (considering within an appeal against decision on the environmental conditions) shall not result in instituting separate proceedings regarding the appealed cooperation acts, it does not provide grounds either to adjudicate in form of a separate administrative act of justifiability of the raised objections. Consideration by the appeals authority of the objections raised against the cooperation act issued by the RDEP, acting as a cooperating authority, resulted in overruling the decision on the environmental conditions, and not only the cooperation act of RDEP ${ }^{48}$. Furthermore, the appeals authority competent to examine the appeal against the decision on the environmental conditions is an authority superior to the one conducting the main proceedings, and not the authority superior to the cooperating one. The appeals authority, in that case, was, therefore, the self-government appeals court, which did not possess the know-how in environmental protection and had to verify objections against environmental constraints regarding an investment implementation. In case an inappropriately verified decision becomes final, the investor takes a risk that in the future (in an extraordinary mode) such a decision may be revoked, and the investment process commenced may be blocked.

Thirdly, regulations of the law on the access to information (...) excluded the possibility of applying against RDEP any legal measures to counteract the authority's tardiness (i.e. reminders) ${ }^{49}$. No deadlines were established either for issuing cooperation act by RDEP as the cooperating authority (in case of other authorities such deadlines are established).

47 Consolidated text Dziennik Ustaw (English: Journal of Laws) of 2017, item 1405 as amended.

48 Małgorzata Szalewska, supra note 44, 117-118.

49 Ibidem. 
Provisions of the act on wind-farms have amended art. 75 item 1 of the law on access to information (...). The authority appropriate to issue a decision on environmental conditions for a wind farm of over $40 \mathrm{~kW}$ capacity is currently RDEP. The institution of cooperating has thus been excluded at least in the relation between the commune's executive authority and RDEP. The aforesaid doubts remain however up-to-date to some extent with regard to other authorities cooperating in the process of issuing decisions on environmental conditions for wind farms.

In order for an institution of cooperation to assure acceleration and improvement of administrative procedures, it must be properly constructed and applied. The authority examining the case must be equipped with legal instruments that shall guarantee the proper course of the cooperation. An example of such a measure might be, introduced since 1 June $2017^{50}$ into the Polish administrative procedure code, the right of case resolving authority to summon a meeting within the cooperation mode, in case it might expedite another authority's taking their stand (art. 106a of the administrative procedure code), as well as bestow the rank of general rule of administrative procedure to the obligation of authorities to actively cooperate with one another at full explanation of the case by means of relevant measures (art. $7 \mathrm{~b}$ of the administrative procedure code) ${ }^{51}$.

\section{SUMMARY}

The lack of proper coordination in activities of public administration authorities within the process of authorization, certification and licensing of RES investments is still »the dominant barrier of efficient administrative procedures in the field of RES investment. It seems that the reason for the above is that the investment process regarding RES (in particular

50 Ustawa z 7 kwietnia 2017 r. o zmianie ustawy - Kodeks postępowania administracyjnego oraz niektórych innych ustaw usprawnienia (The Act of 7 April 2017 amending the act - Code of Administrative Procedure and some other acts), consolidated text Dziennik Ustaw (English: Journal of Laws) of 2017, item 1257.

51 Piotr Marek Przybysz, Komentarz do art. 7 (b) Kodeksu postępowania administracyjnego, In: Piotr Marek Przybysz. Kodeks postępowania administracyjnego. Komentarz aktualizowany. LEX/el/2019. 
in the field of large investments regarding wind and water energy) is regulated by many (a "maze") of acts in different areas of law, often requiring know-how in different fields. The above-mentioned reason makes often impossible to indicate the authority capable to resolve few cases in which highly specialized knowledge is not required.

Bearing in mind the need to respect the principle of institutional and procedural autonomy, which - as it must be emphasized - is not an absolutely binding rule (this principle's limitations are allowed). The EU legislator has left a considerable scope of discretion to the Member States with regard to the coordination form of public administration authorities' actions in the process of issuing permissions or other types of approvals necessary to carry out RES investments. It must be remembered though that the way the obligation is interpreted is related to the increase of $\mathrm{EU}$ requirements with regard to the expected level of RES. Each of the Member States is obliged to achieve a designated (regularly increased) RES energy share in the final gross energy consumption (which shall not be achieved unless proper administrative procedures are introduced). The lack of proper coordination in activities of public administration authorities influences a delay of RES overall investment process, which as a result leads to a slowdown in a designated share of RES to gross final energy consumption.

Having awareness of the above, the Member States have introduced different forms of coordinating public administration authorities activity in the process of RES investments' authorization, certification and licensing. Such coordination may be based on coordinating the course of all procedures and even taking over conducting all procedures concerning permissions or other types of approvals by an administrative one-stop-shop. A certain form of public administration authority activities' coordination may also be the institution of cooperation between authority resolving the case and opinionating or agreeing authorities (acting within one proceeding).

Constructing and applying coordination of public administration authorities in such a way as it might contribute to streamlining and accelerating administrative procedures in the area of RES investments is not an easy task for the national legislator. Inappropriately constructed and applied mechanisms may lead to an exactly opposite effect. The national legislator certainly shall not achieve the effect of streamlining and expediting administrative procedures "at the expense" of rights and freedoms 
(mainly with regard to entitlements connected with the institution of public participation or the right to file the measures of appeal. We will certainly not achieve an expected result either at the "expense" of values and objectives for accomplishing of which the administrative procedures subject to coordination have been established (environmental protection, spatial order, public safety), or the constitutional principles for shaping the structure and competence of administrative authorities established in a given Member State. Decisions issued in such proceedings shall raise public objections, doubts as to their material and procedural accuracy and they will be "opposed" or challenged by means of appeal, which shall lengthen the whole investment process.

Constructing and using administrative procedures within RES investments requires therefore careful analysis of various values and interests. It is also important to realize that each model of administration authorities' coordination has its advantages and disadvantages. A specific model of coordination must be adjusted to a particular RES undertaking. With reference to one type of RES undertakings, it may bring positive effects, in other cases negative ones, which may additionally bring different effects in the different Member States. In many cases, the effectiveness of such mechanisms may even depend on a particular RES actual stage of implementation. The national legislator ought to consider the validity of constructing regulations in a way allowing authorities to apply certain solutions (depending on the state of fact), and not obligate them to follow regulations uncompromisingly.

We must also bear in mind that lack of coordination in activities of public administration authorities is only one (out of three) reasons for a delay in the whole RES investment process, which in consequence leads to a slowdown in meeting a particular contribution of RES to gross final energy consumption. By introducing regulations for coordination of administration authorities' activity, the national legislator ought to apply this in a wider context, i.e. allow thereby to overcome the barriers to the RES investment process. Only the broad-based solutions may yield the desired effect. 


\section{REFERENCES}

Biernat, Stanisław. 1979. Działania wspólne w administracji państwowej. Wrocław: Zakład Narodowy im. Ossolińskich.

Bohdan, Anna. Przybylska, Monika. 2015. Podstawy prawne odnawialnych źródeł energii i gospodarki odpadami w Polsce. Warsaw: C.H. Beck.

Bukowski, Zbigniew. 2017. „Aksjologiczne podstawy stanowienia prawa ochrony środowiska”, In: Aksjologia prawa administracyjnego. Vol. II”, ed. Jan Zimmermann, 233-241. Warsaw: Wolters Kluwer.

Brzeziński, Piotr. 2010. Unijny obowiązek odmowy zastosowania przez sąd krajowy ustawy niezgodnej z dyrektywą Unii Europejskiej. Warsaw: Wolters Kluwer.

Dąbek, Dorota. Zimmermann, Jan. 2005. „Decentralizacja poprzez samorząd terytorialny w ustawodawstwie i orzecznictwie prokonstytucyjnym". In: Samorząd terytorialny. Zasady ustrojowe i praktyka. ed Paweł Sarnecki, 7-29. Warsaw: Gandalf.

De Graaf, Kars. Tolsma, Hanna. 2015. "Country Report: The Netherlands. The Future Environment and Planning Act and the Impact of the Crisis and Recovery Act”. IUCN Academy of Environmental Law e-Journal 6 (5): 293-302.

De Graaf, Kars. Marseille, Albert. 2014. "Towards efficient administrative procedures for renewable energy projects? The Dutch experience with the Crisis and Recovery Act". In: Renewable Energy Law in the EU: Legal Perspectives on Bottom up-approaches. ed. Marjan Peeters, Thomas Schomerus, 123-143. Cheltenham-Northampton: Edward Elgar Publishing.

Dobrowolski, Grzegorz. 2012. „Organy właściwe do wydania decyzji o środowiskowych uwarunkowaniach". In: Ocena modelu prawnego organizacji ochrony środowiska w Polsce i na Słowacji. ed. Elżbieta Ura, Jerzy Stelmasiak, Stanisław Pieprzny, 281-292. Rzeszów: RS. DRUK.

Dolnicki, Bogdan. Tarno, Jan P. (ed.). 2012. Samorząd terytorialny w Polsce a samorządowa kontrola administracji. Warsaw: Wolters Kluwer.

Gajewski, Sebastian. 2016. „Wzruszenie ostatecznej decyzji administracyjnej z powodu jej niezgodności z wykładnią prawa UE przyjętą w późniejszym orzeczeniu TSUE (w świetle k.p.a.)". In: Europeizacja prawa administracyjnego i administracji publicznej. ed. Ewa Wójcicka, Bogusława Przywor, 167-177. Częstochowa: Akademia im. Jana Długosza w Częstochowie.

Jesse, Katinka. 2013. "Country Report: The Netherlands. Big Changes in Environmental Planning Law On The Way". IUCN Academy of Environmental Law e-Journal 4: 178-185.

Kmieciak, Zbigniew. 2009. "Zasada autonomii proceduralnej państw członkowskich UE i jej konsekwencje dla procesu orzekania przez sądy administracyjne 
i organy administracji publicznej”. Zeszyty Naukowe Sądownictwa Administracyjnego 2: 9-25.

Marszał, Katarzyna. 2012. "Wpływ czynników zewnętrznych na samorząd terytorialny - analiza czynników ograniczających samodzielność jednostek samorządu terytorialnego". In: Samorząd terytorialny w Polsce a samorządowa kontrola administracji. ed. Dolnicki Bogdan, Jan Paweł Tarno, 227-246, Warsaw: Wolter Kluwer.

Nowacka, Ewa Jolanta. 2010. Samorząd terytorialny jako forma decentralizacji administracji publicznej, 15-31, Warsaw: Lexis Nexis.

Peters, Marjan. Schomerous, Thomas. 2014. "An UE law perspective on the role of regional authorities in the field of renewable energy". In: Renewable Energy Law in the EU: Legal Perspectives on Bottom up-approaches. ed. Marjan Peeters, Thomas Schomerous, 10-32. Cheltenham-Northampton: Edward Elgar Publishing.

Przybysz, Piotr Marek. Komentarz do art. 7 (b) Kodeksu postępowania administracyjnego. In: Piotr Marek Przybysz. Kodeks postępowania administracyjnego. Komentarz aktualizowany. LEX/el/2019

Sypniewski, Dominik. 2017. "Bezpieczeństwo jako wartość podlegająca ochronie w procesie budowlanym". In: Aksjologia prawa administracyjnego. Vol II. ed. Jan Zimmermann, 595-604. Warsaw: Wolters Kluwer.

Szalewska, Małgorzata. 2017. ”Współdziałanie organów administracji publicznej w procedurze wydawania decyzji o środowiskowych uwarunkowaniach przedsięwzięcia”. In: Oceny oddziaływania na środowisko w praktyce. ed. Bartosz Rakoczy, 81-126. Warsaw: Wolters Kluwer.

Szewczak, Marek. 2017. „Aksjologia prawa zagospodarowania przestrzeni”. In: Aksjologia prawa administracyjnego. Vol. II. ed. J. Zimmermann, 233-242. Warsaw: Wolters Kluwer,

Szyrski, Mariusz. 2017. Rola samorządu terytorialnego w rozwoju odnawialnych źródeł energii (OZE). Analiza administracyjnoprawna. Warsaw: Wolters Kluwer.

Taborowski, Maciej. 2012. Konsekwencje naruszenia prawa Unii Europejskiej przez sądy krajowe. Warsaw: Wolters Kluwer.

Wróbel, Andrzej. 2005. ”Autonomia proceduralna państw członkowskich. Zasada efektywności i zasada efektywnej ochrony sądowej w prawie Unii Europejskiej”. Ruch Prawniczy, Ekonomiczny i Socjologiczny LXVII, zeszyt 1: 35-58.

Verschuuren, Jonathan. 2010. "The Dutch Crisis and Recovery Act: Economic Recovery and Legal Crisis?”. Potchefstroom Electronic Law Journal 5(13): 5-21. Zimmermann, Jan. 2012. Prawo administracyjne. Warsaw: Wolters Kluwer. 